\title{
Elazığ’da Üretilen Balların Bazı Toksik Ağır Metal Düzeyleri
}

\author{
Osman AYGÜN* \\ Gıda İşleme Bölümü, Keban Meslek Yüksekokulu, Fırat Üniversitesi, Keban / Elazı̆̆g, Türkiye \\ *oaygun@ firat.edu.tr
}

(Geliș/Received: 17/07/2019;

Kabul/Accepted: 07/02/2020)

\begin{abstract}
Öz: $\mathrm{Bu}$ çalışmada, Elazı̆̆'da üretilen ballarda bazı toksik ağır metal düzeylerinin belirlenmesi amaçlandı. Bunun için Elazı ̆̆' daki çeşitli marketlerden ve şarküterilerden toplanan 30 adet doğal süzme bal örneğinde alüminyum (Al), arsenik (As), kadmiyum $(\mathrm{Cd})$ ve kurşun $(\mathrm{Pb})$ düzeyleri analiz edildi. Bal örneklerinin metal içerikleri, mikrodalga ünitesinde yakma işlemi sonrasında ICP-MS cihazı ile belirlendi. Örneklerde bulunan Al, As, Cd ve Pb miktarları sirasıyla 435,9 $\mu \mathrm{g} / \mathrm{kg}, 4,8 \mu \mathrm{g} / \mathrm{kg}$, $337,9 \mu \mathrm{g} / \mathrm{kg}$ ve $409,9 \mu \mathrm{g} / \mathrm{kg}$ olarak tespit edildi. Analiz edilen bal örneklerinde miktar bakımından en çok bulunan toksik ağır metallerin $\mathrm{Al}, \mathrm{Pb}, \mathrm{Cd}$ ve As şeklinde sıralandığı görüldü. Sonuç olarak, bal örneklerindeki Al ve As düzeylerinin insan sağlığı açısından risk oluşturmayacak derecede düşük olduğu, buna karşılık $\mathrm{Cd}$ ve $\mathrm{Pb}$ düzeylerinin tüketici sağlığı açısından potansiyel bir risk oluşturabileceği kanaatine varıldı.
\end{abstract}

Anahtar kelimeler: Bal, ağır metal, Elazığ.

\section{Some Toxic Heavy Metal Levels of Honeys Produced in Elazig}

\begin{abstract}
In this study, it was aimed to determine some toxic heavy metal levels of honeys produced in Elazig. For this purpose, aluminum $(\mathrm{Al})$, arsenic $(\mathrm{As})$, cadmium $(\mathrm{Cd})$ and lead $(\mathrm{Pb})$ levels of 30 natural liquid honey samples collected from various markets and delicatessens in Elazig were analyzed. The metal contents of honey samples were determined by ICP-MS device after the microwave digestion process. The amounts of $\mathrm{Al}, \mathrm{As}, \mathrm{Cd}$ and $\mathrm{Pb}$ in the samples were 435,9 $\mu \mathrm{g} / \mathrm{kg}, 4,8 \mu \mathrm{g} / \mathrm{kg}, 337,9$ $\mu \mathrm{g} \mathrm{kg}$ and $409,9 \mu \mathrm{g} / \mathrm{kg}$, respectively. The highest amount of toxic heavy metals in the honey samples were determined as $\mathrm{Al}$, $\mathrm{Pb}, \mathrm{Cd}$ and As, respectively. As a result, it was concluded that the levels of $\mathrm{Al}$ and As in honey samples were low enough not to pose a risk to human health, whereas $\mathrm{Cd}$ and $\mathrm{Pb}$ levels could pose a potential risk to consumer health.
\end{abstract}

Key words: Honey, heavy metal, Elazig.

\section{Giriş}

Bal, "Bal arılarının bitki nektarından, bitkilerin canlı kısımlarının salgılarından veya bitkilerin canlı parçaları üzerinde yaşayan bitki emici böceklerin salgılarından topladığı, kendine özgü maddelerle değişikliğe uğratıp su içeriğini azalttığı ve petekte depolayarak olgunlaştırdığı doğal bir hayvansal ürün” olarak tanımlanmaktadır [1]. Bal, ülkemizde yaygın olarak tüketilen, ihracatta tercih edilen ve ülke ekonomisine büyük katkı sağlayan önemli bir hayvansal gıda maddesidir. Türkiye'de, 2016 yılında yaklaşık 106 bin ton düzeyinde bal üretimi gerçekleştirilmiştir. Diğer bir ifade ile Türkiye, dünya bal üretim sıralamasında Çin'den sonra ikinci sırada yer almaktadır [2].

Bal, özellikle karbonhidratlar, amino asitler, vitaminler, fenoller, enzimler ve mineraller gibi birçok temel besin maddesini içermektedir; bu nedenle hem besleyici olması ve hem de antibakteriyel, antifungal ve antiviral etkilerinden dolayı insan beslenmesinde ve tıpta önemli bir yere sahiptir [3]. Balın, içerdiği flavonoidler ve fenolik asitlerin gösterdikleri yüksek antioksidan ve antienflamatuar etkilerden dolayı antikanser ve antidiyabetik aktivite gösterdiğĭ, kalp-damar sisteminde, esas olarak düşük yoğunluklu lipoproteinlerin oksidasyonunu önlediği, sinir ve solunum sistemlerinde ve gastrointestinal sistemde, astım ve bakteriyel enfeksiyonlara karşı da koruyucu bir etkiye sahip olduğu bildirilmektedir [3, 4]. Balların bileșimi ve özellikleri, öncelikle nektarın veya bal özünün botanik kökenine, iklime, coğrafik bölgelere, bal arısı türlerine bağlı olarak değişiklik göstermektedir. Bununla beraber, hasat işlemi, ambalajlama ve depolama da balın nitelikleri üzerinde etkili faktörler arasında yer almaktadır $[5,6]$. Ballardaki metal konsantrasyonlarının ise, büyük ölçüde botanik ve coğrafi kökenleri bakımından çiçeklerin temel bileşimine bağlı olduğu rapor edilmektedir [7]. Balın içerdiği başlıca iz elementler arasında $\mathrm{K}, \mathrm{P}, \mathrm{Mg}, \mathrm{Al}, \mathrm{Ca}, \mathrm{Na}$, $\mathrm{Fe}, \mathrm{Mn}, \mathrm{Cu}$ ve $\mathrm{Zn}$ gibi mineraller sayılmaktadır [3].

\footnotetext{
* Sorumlu yazar: oaygun@ firat.edu.tr. Yazarın ORCID Numarası: 0000-0002-4328-052X
} 
Bal, insanların ihtiyaç duyduğu başlıca mineral ve iz elementlerin iyi bir kaynağı olarak görülmektedir. Ancak, gıda yoluyla alınan bazı elementlerin güvenlik seviyelerini aştıklarında toksik olabildiği de rapor edilmektedir [7]. $\mathrm{Na}, \mathrm{K}, \mathrm{Ca}, \mathrm{Zn}, \mathrm{Fe}$ ve $\mathrm{Cu}$ gibi metallerin, insan vücudunda bazı biyokimyasal ve fizyolojik fonksiyonlar için önemli ve yaşam boyunca sağlığı korumak için gerekli olduğu, ancak Pb, As, Cd ve Hg gibi ağır metallerin özellikle toksik olduğu, bu metallerin gıdalarda aşırı miktarlarda bulunmasının, bazı hastalıklara, özellikle de kalp - damar, böbrek, solunum, sinir ve kemik hastalıklarına neden oldukları [8], Al'un sinir, kemik ve hemopoietik hücreler üzerinde zararlı etkileri bulunduğu ve Parkinson hastalığı gibi bazı nörodejeneratif hastalıklarla ilişkili olduğu $[9,10]$ bildirilmektedir.

Çevrenin ağır metallerle kontaminasyonu, beslenme ve çevresel nedenlerden dolayı günümüzde önemi gittikçe artan bir sorun haline gelmiştir. Çevrenin ağır metallerle kontaminasyonuna yol açan kaynaklar arasında toprak erozyonu, yer kabuğunun doğal yıpranması, madencilik, endüstriyel atıklar, kentleşme, kanalizasyon suları, tarım ilaçları vb. sayılmaktadır [9]. İnsan beslenmesinde ve tıpta önemli bir yere sahip olan balların da, endüstriyel kirlilik, bala uygulanan hatalı işlemler ve zirai kimyasal maddeler gibi dış kaynaklar vasıtasıyla ağır metal kontaminasyonuna maruz kalabileceği rapor edilmiştir [5]. Sanayi alanları ve araç trafiğinden dolayı havada ve suda, arı ve arı ürünlerini de kontamine edebilen ağır metaller bulunabileceği gibi, özellikle yoğun araç trafiğinden dolayı $\mathrm{Al}, \mathrm{Ca}, \mathrm{Cu}, \mathrm{Fe}, \mathrm{Pb}, \mathrm{Mg}, \mathrm{Si}, \mathrm{Zn}, \mathrm{Ba}, \mathrm{Cd}, \mathrm{Ni}, \mathrm{Pd}$, Pt gibi ağır metaller de havaya ve çevreye yayılabilmektedir $[8,11]$. Bu bağlamda, arı ve arı ürünlerinden, çevrenin kirliliğinin belirlenmesinde biyoindikatör olarak da faydalanılabileceği bildirilmiştir [11, 12].

Yapılan literatür taramasında, Elazı̆̆'da üretilen balların ağır metal düzeyleri konusunda herhangi bir araştırmaya rastlanmamıştır. Bu çalışmanın amacı, Elazı ̆̆' da üretilen ballarda çevre kirliliğine neden olan önemli toksik ağır metaller arasında yer alan $\mathrm{Al}, \mathrm{As}, \mathrm{Cd}$ ve $\mathrm{Pb}$ düzeylerinin belirlenmesidir.

\section{Materyal ve Metot}

\subsection{Materyal}

Bal örnekleri, Elazı̆̆’’da çeşitli şarküteri ve marketlerden ve arıcılardan $(\sim 200 \mathrm{~g})$ temin edildi. Çalışma kapsamında doğal süzme baldan oluşan toplam 30 adet bal örneği analize alınıncaya kadar küçük cam kavanozlarda, oda sıcaklığında ve karanlıkta muhafaza edildi.

\subsection{Metot}

Toplam 30 adet bal örneği Al, As, Cd ve Pb içerikleri bakımından analiz edildi. Analizler Bayburt Üniversitesi Merkezi Araştırma Laboratuvarı'nda yapıldı. Analiz öncesinde bal örnekleri, organik bileşiklerin yok edilmesi ve inorganik bileşiklerin de çözünür faza geçirilmesi için çözümleme işlemine tabi tutuldu. Bu amaçla $500 \mathrm{mg}$ bal numunesi üzerine $1 \mathrm{ml} \mathrm{H} \mathrm{O}_{2}(\% 35)$ ve $9 \mathrm{ml}$ suprapur $\mathrm{HNO}_{3}(\% 65)$ ilave edildi. Örnekleri yakma işlemi, mikrodalga yakma ünitesi (Milestone Ethos UP, Italy) kullanılarak gerçekleştirildi. Örnekler, mikrodalga yakma ünitesinin çalışma koşullarına göre (Tablo 1) 15 dakikalık yakma ve 20 dakikalık soğutmadan sonra bidistile su ile $50 \mathrm{ml}$ 'ye tamamlanarak analize hazır hale getirildi. Örneklerin mineral madde düzeyleri ICP-MS (Inductively coupled plasma with mass spectrometry) cihazı (Agilent, 7800, USA) ile analiz edildi. ICP-MS cihazının çalışma koşulları ve analiz parametreleri Tablo 2'de verilmiştir.

Tablo 1. Mikrodalga yakma ünitesinin çalışma koşulları.

\begin{tabular}{|l|l|l|l|}
\hline Basamak & \multicolumn{1}{|c|}{ Süre } & \multicolumn{1}{|c|}{ Sıcaklık } & Güç \\
\hline 1 & $20 \mathrm{dk}$ & $210^{\circ} \mathrm{C}$ & $1800 \mathrm{~W}$ \\
2 & $15 \mathrm{dk}$ & $210^{\circ} \mathrm{C}$ & $1800 \mathrm{~W}$ \\
\hline
\end{tabular}


Tablo 2. ICP-MS cihazının çalışma koşulları.

\begin{tabular}{|c|c|}
\hline Parametre & Çalışma Koşulları \\
\hline RF gücü (RF power) & $1550 \mathrm{~W}$ \\
\hline RF eşleştirme (RF matching) & $1.4 \mathrm{~V}$ \\
\hline H Torku (Torch H) & $0,1 \mathrm{~mm}$ \\
\hline V Torku (Torch V) & $0,3 \mathrm{~mm}$ \\
\hline Diskriminatör (Discriminator) & $4,1 \mathrm{mV}$ \\
\hline Plazma gazı (Plasma gas) & $15,02 \mathrm{~L} / \mathrm{dk}$ \\
\hline Plazma taşıyıcı gazı (Plasma carrier gas) & $1.05 \mathrm{~L} / \mathrm{dk}$ \\
\hline Yardımcı gaz akışı (Auxiliary gas) & $0,9 \mathrm{~L} / \mathrm{dk}$ \\
\hline He gazı (He gas) & $0,0244 \mathrm{ml} / \mathrm{dk}$ \\
\hline Entegrasyon süresi (Integration time) & $0,1 \mathrm{sn}$ \\
\hline Kazanım süresi (Acquisition time) & $23 \mathrm{sn}$ \\
\hline Nebülizatör tipi (Nebulizer type) & MicroMist \\
\hline Nebülizatör pompası (Nebulizer pump) & $0.1 \mathrm{rps}$ \\
\hline Örnek giriş tipi (Sample introduction type) & Peripump \\
\hline Örnek derinliği (Sample depth) & $8 \mathrm{~mm}$ \\
\hline Örnekleme periyodu (Sampling period) & $0,311 \mathrm{sn}$ \\
\hline İyon lens modeli (Ion lenses model) & X-lens \\
\hline Omega bias (Omega bias) & $-80 \mathrm{~V}$ \\
\hline Omega lens (Omega Lens) & $9,6 \mathrm{~V}$ \\
\hline Hücre girişi (Cell entrance) & $-30 \mathrm{~V}$ \\
\hline Hücre çıkışı (Cell exit) & $-50 \mathrm{~V}$ \\
\hline Hücre sicaklığ 1 (Cell temperature) & $64,98^{\circ} \mathrm{C}$ \\
\hline Hücre 1sitıc1 voltaj1 (Cell heater voltage) & $3,72 \mathrm{~V}$ \\
\hline
\end{tabular}

\subsection{Verilerin değerlendirilmesi}

Çalışma sonunda elde edilen sayısal sonuçların en düşük, en yüksek ve ortalama değerleriyle standart sapma değerleri Microsoft Office Excel 2016 paket programı kullanılarak elde edilmiştir.

\section{Sonuçlar}

Bu çalışmada analiz edilen bal örneklerinde bulunan ağır metallerin en düşük, en yüksek ve ortalama miktarları Tablo 3'de verilmiştir. Analiz edilen toplam 30 adet bal örneğinde miktar bakımından en fazla bulunan ağır metallerin $\mathrm{Al}, \mathrm{Pb}, \mathrm{Cd}$ ve As şeklinde sıralandığı belirlendi.

\section{Tartısma}

Bal, içerdiği temel besin öğeleri ve gösterdiği çeşitli farmakolojik (antibakteriyel, antifungal, antiviral vb.) etkilerden dolayı insan beslenmesinde ve tıpta önemli bir yere sahiptir [3]. Bal, aynı zamanda çevre kirliliğinin bir göstergesi olarak kullanılabilecek önemli bir gıda maddesidir. Arıların yaklaşık $3 \mathrm{~km}$ yarıçapındaki bir alanda yoğun şekilde uçtukları ve bu nedenle çevre kontaminasyonunun belirlenmesinde arı ve arı ürünlerinden biyoindikatör olarak faydalanılabileceği bildirilmektedir [11, 12]. Yapılan literatür taramasında, Elazığ'da üretilen ve tüketilen balların ağır metal düzeyleri konusunda bugüne kadar yapılmış herhangi bir araştırmaya rastlanmamıștır. $\mathrm{Al}, \mathrm{As}, \mathrm{Cd}$ ve $\mathrm{Pb}$, endüstriyel faaliyetler sonucu meydana gelen çevre kirliliğine neden olan önemli toksik ağır metaller arasında sayılmaktadır $[5,10]$. Bu çalışma ile Elazığ'da üretilen ve tüketime sunulan balların bazı toksik ağır metal düzeylerinin ( $\mathrm{Al}, \mathrm{As}, \mathrm{Cd}$ ve $\mathrm{Pb}$ ) belirlenmesi amaçlanmıştır.

$\mathrm{Bu}$ çalışmada, bal örneklerinde analizi yapılan ağır metallerden en fazla Al'un bulunduğu, bunu sırasıyla $\mathrm{Pb}$, Cd ve As'in takip ettiği belirlenmiştir. Bal örneklerinde analiz edilen ağır metal konsantrasyonlarının en düşük ve en yüksek değerlerinin, ortalama değerlerden oldukça farklı bulunması, ağır metal düzeylerinde standart sapmanın oldukça yüksek çıkmasına neden olmuştur. Bu durum, bal örneklerinin üretildiği yerlerin coğrafik koşulları, florası, otoyollara ve sanayi alanlarına olan uzaklı̆̆ı, balın depolanması, işlenmesi ve nakliyesi sırasında metal kaplar veya ekipmanla temas gibi çeșitli faktörlerden [11] kaynaklanmış olabilir.

Analiz edilen bal örneklerindeki en düşük Al miktarı $0,0 \mu \mathrm{g} / \mathrm{kg}$, en yüksek 1112,9 $\mu \mathrm{g} / \mathrm{kg}$, ortalama 435,9 $\mu \mathrm{g} / \mathrm{kg}$ olarak tespit edilmiştir (Tablo 3). Tuzen ve ark. [13], yaptıkları araştırmada Türkiye'de üretilen bal örneklerinde en düşük Al konsantrasyonunu $(83 \mu \mathrm{g} / \mathrm{kg})$ Ankara, en yüksek konsantrasyonunu ise $(325 \mu \mathrm{g} / \mathrm{kg})$ Kayseri ballarında tespit etmişlerdir. Yarsan ve ark.' larının [11] çalışmalarında ise, Türkiye'nin farklı bölgelerinde üretilen ballardaki Al miktarı 7210-19120 $\mu \mathrm{g} / \mathrm{kg}$ aralığında bulunmuştur. Altun ve ark. [14], Doğu ve Güneydoğu 
Tablo 3. Analiz edilen 30 adet bal örneğinin ağır metal düzeyleri $(\mu \mathrm{g} / \mathrm{kg})$.

\begin{tabular}{|l|l|l|l|l|}
\hline Numune & Al & As & Cd & Pb \\
\hline 1 & 774,5 & 4,3 & 0,0 & 195,5 \\
2 & 0,0 & 5,0 & 201,6 & 29,8 \\
3 & 1001,9 & 6,2 & 49,6 & 56,9 \\
4 & 0,0 & 4,3 & 145,2 & 0,0 \\
5 & 791,2 & 3,1 & 3514,1 & 149,5 \\
6 & 995,3 & 5,9 & 111,9 & 16,2 \\
7 & 0,0 & 1,5 & 93,0 & 120,6 \\
8 & 0,0 & 1,3 & 123,4 & 922,8 \\
9 & 0,0 & 65,9 & 225,2 & 0,0 \\
10 & 82,8 & 1,2 & 155,9 & 41,3 \\
11 & 771,6 & 0,4 & 86,1 & 33,2 \\
12 & 538,5 & 1,2 & 162,5 & 357,9 \\
13 & 750,5 & 1,7 & 97,1 & 117,5 \\
14 & 381,8 & 1,6 & 222,7 & 25,2 \\
15 & 490,6 & 1,2 & 562,2 & 223,5 \\
16 & 142,0 & 4,0 & 87,3 & 0,0 \\
17 & 696,0 & 4,0 & 289,0 & 274,2 \\
18 & 818,5 & 6,6 & 117,8 & 145,5 \\
19 & 858,9 & 1,3 & 0,0 & 2911,4 \\
20 & 1112,9 & 2,6 & 0,0 & 106,4 \\
21 & 177,8 & 1,0 & 0,0 & 797,5 \\
22 & 841,3 & 1,1 & 0,0 & 87,1 \\
23 & 312,8 & 0,8 & 27,9 & 0,0 \\
24 & 76,8 & 15,4 & 39,5 & 0,0 \\
25 & 204,2 & 0,2 & 5,8 & 0,0 \\
26 & 63,2 & 1,0 & 0,0 & 0,0 \\
27 & 455,1 & 3,0 & 0,0 & 5051,7 \\
28 & 0,0 & 0,0 & 1605,5 & 0,0 \\
29 & 334,4 & 0,0 & 1114,6 & 609,2 \\
30 & 407,1 & 0,0 & 1101,1 & 25,6 \\
En Düsük & 0,0 & 0,0 & 0,0 & 0,0 \\
En Yüksek & 1112,9 & 65,9 & 3514,1 & 5051,7 \\
Ortalama ve & $435,9 \pm 365,9$ & $4,8 \pm 11,9$ & $337,9 \pm 710,6$ & $409,9 \pm 1037,2$ \\
standart sapma & & & & \\
& & & & \\
\hline
\end{tabular}

Bölgelerinde elde ettikleri bal örneklerinde ortalama 69,7 (<1 - 960) $\mu \mathrm{g} / \mathrm{kg}$ Al bulunduğunu saptamışlardır. Bir başka araştırmada [15] ise, ülkemizin farklı bölgelerinde üretilen ballarda bulunan Al miktarı $775-155585 \mu \mathrm{g} / \mathrm{kg}$ aralığında, ortalama $15299 \mu \mathrm{g} / \mathrm{kg}$ olarak bulunmuştur. İran'ın çeşitli bölgelerinde üretilen ballarda bulunan Al konsantrasyonu ortalama $9620(1850$ - 17400) $\mu \mathrm{g} / \mathrm{kg}$ [16], Macaristan ballarında ise ortalama $1030(4-4390)$ $\mu \mathrm{g} / \mathrm{kg}$ [5] düzeyinde tespit edilmiştir. Bu çalışmamızda bal örneklerinde saptanan Al miktarları Czipa ve ark. [5], Yarsan ve ark. [11], Altunatmaz ve ark. [15] ve Akbari ve ark.'nın [16] sonuçlarından düşük, Tuzen ve ark. [13] ve Altun ve ark.'nın [14] sonuçlarından ise nispeten yüksektir. Balda bulunabilecek maksimum Al miktarı Türk Gıda Kodeksi Bulaşanlar Yönetmeliği’nde [17] ve AB mevzuatında [18] belirtilmemiştir. Balda bulunan, ancak maksimum limitleri belirlenmemiş ağır metal miktarlarının tüketici sağlığı üzerine etkileri, geçici tolere edilebilir maksimum haftalık alım miktarları (PTWI) göz önüne alınarak tartışılabilmektedir $[5,16]$. İnsanlar tarafindan tüketilen gıdalardaki Al bileşikleri için PTWI değeri, Gıda ve Tarım Örgütü / Dünya Sağlık Örgütü Gıda Katkı Maddeleri Uzman Komitesi (JECFA) tarafından $1 \mathrm{mg} / \mathrm{kg}$ (günlük $0,142 \mathrm{mg} / \mathrm{kg}$ ) canlı ağırlık olarak belirlenmiştir [19]. Yetişkin bir insanın $(60 \mathrm{~kg})$ bir günde tüketebileceği bal miktarının $15 \mathrm{~g}$ düzeyinde olduğu [20] dikkate alındığında, bu çalışmamızda bal örneklerinde tespit edilen en yüksek Al miktarının $(1113 \mu \mathrm{g} / \mathrm{kg})$ insan sağlığını etkilemeyecek düzeyde olduğu söylenebilir. Alüminyumun, inşaatlarda, otomobillerde ve uçak yapımında kullanılan yapısal malzemeler, ambalaj malzemeleri, çeşitli kaplar ve mutfak eşyaları ve eczacılık ürünleri de dahil olmak üzere çok çeşitli uygulamalarda kullanım alanı bulunduğu ve kömür yanması, madencilik ve tarım gibi faaliyetlerden kaynaklanan toprak kaynaklı tozlarla çevreye yayılmaktadır [19]. Alüminyumun sinir, kemik ve hemopoietik hücreler üzerinde zararlı etkilere ve Parkinson hastalı̆̆ gibi bazı nörodejeneratif hastalıklara neden olduğu rapor edilmiştir $[9,10]$. Bal örneklerinde tespit edilen Al'un, muhtemelen balların işlenmesi sırasında arııılık ekipmanı (alüminyum bal çıkarıcı, alüminyum kaplar vb.) ile kontaminasyonundan kaynaklanmış olabilir [13].

Arsenik, volkanik aktivite ve minerallerin ayrışması gibi doğal kaynaklardan ve madenlerin eritilmesi, kömür yanması ve arsenik esaslı ahşap koruyucular, pestisitler ve tıp ve veteriner ilaçları gibi uygulamalarla çevreye yayılmaktadır [19]. Bu çalışmada incelenen bal örneklerindeki As miktarı 0,0 - 65,9 $\mu \mathrm{g} / \mathrm{kg}$ arasında, ortalama 4,8 
$\mu \mathrm{g} / \mathrm{kg}$ düzeyinde tespit edilmiştir (Tablo 3). Döker ve ark. [21], Çankırı piyasasından topladıkları 7 adet bal örneğinde en düşük As konsantrasyonunu 10,40 $\mu \mathrm{g} / \mathrm{kg}$, en yüksek konsantrasyonu ise 24,30 $\mu \mathrm{g} / \mathrm{kg}$, ortalama 14,7 $\mu \mathrm{g} / \mathrm{kg}$ olarak tespit etmişlerdir. Arsenik konsantrasyonu, İran' ın çeşitli bölgelerinde üretilen ballarda ortalama 160 $(80-400) \mu \mathrm{g} / \mathrm{kg}$ [16] ve $110(80-160) \mu \mathrm{g} / \mathrm{kg}$ [22], Macaristan'da üretilen ballarda ortalama 15,9 $(3,19-30,4)$ $\mu \mathrm{g} / \mathrm{kg}$ [5], Romanya'da üretilen ballarda ise ortalama $6,9(2,3-14,9) \mu \mathrm{g} / \mathrm{kg}$ olarak tespit edilmiştir [23]. Bu çalışmamızda bal örneklerinde saptanan As miktarları, yukarıda bahsedilen araştırma sonuçlarından daha düşüktür. İnorganik arsenik, Uluslararası Kanser Araştırma Ajansı (IARC) tarafından insanlar için kanserojen madde olarak tanımlanmaktadır [19]. Balda bulunabilecek As miktarı Türk Gıda Kodeksi Bulaşanlar Yönetmeliği'nde [17] ve AB mevzuatında [18] belirtilmemiş olmasına rağmen, Tayland'da balda bulunabilecek en yüksek As 0,2 mg/kg olarak belirlenmiştir [24]. Bu çalışmada bal örneklerinde tespit edilen As miktarının, adı geçen ülkedeki maksimum değerden oldukça düşük olduğu, dolayısıyla tüketicilerin sağlığı açısından potansiyel bir risk taşımadığı söylenebilir. Özellikle içme suyunun, diyetle alınan toplam inorganik As miktarında önemli bir kaynak olduğu, içme suyundan kaynaklanan büyük bir katkı olmadıkça, insanlarda tolere edilebilir As miktarının normal olarak aşılamayacağı bildirilmektedir [19].

Bu çalışmada analiz edilen bal örneklerindeki Cd miktarı 0,0 $\mu \mathrm{g} / \mathrm{kg}$, en yüksek 3514,1 $\mu \mathrm{g} / \mathrm{kg}$, ortalama 337,9 $\mu \mathrm{g} / \mathrm{kg}$ olarak saptanmıştır (Tablo 3). Tuzen ve ark. [13], en düşük Cd konsantrasyonunu (0,9 $\mu \mathrm{g} / \mathrm{kg}) \mathrm{Samsun}$ ballarında, en yüksek $\mathrm{Cd}$ konsantrasyonunu ise $(17,9 \mu \mathrm{g} / \mathrm{kg})$ Adana ballarında tespit etmişlerdir. Bir başka araştırmada ise, ülkemizin farklı bölgelerinde üretilen ballarda ortalama $380(0,00-297) \mu \mathrm{g} / \mathrm{kg}$ [15], Kahramanmaraş ballarında ise ortalama $320(310$ - 340) $\mu \mathrm{g} / \mathrm{kg}$ [25] Cd bulunmuştur. Altun ve ark. [14] tarafindan yapılan araştırmada, Doğu ve Güneydoğu illerinde toplanan bal örneklerinde Cd tespit edilmemiștir $(<1 \mu \mathrm{g} / \mathrm{kg})$. İran'ın çeşitli bölgelerinde üretilen ballarda ortalama olarak $390(330-530) \mu \mathrm{g} / \mathrm{kg}$ [16], Macaristan ballarında ortalama $0,746(<0,003-3,31) \mu \mathrm{g} / \mathrm{kg}$ [5], Romanya'nın farklı bölgelerinde üretilen ballarda ise ortalama 2,10 (0,5 - 11,60) $\mu \mathrm{g} / \mathrm{kg}$ [23] Cd bulunduğu saptanmıştır. Bu çalışmamızda bal örneklerinde saptanan Cd miktarları Czipa ve ark., [5], Tuzen ve ark. [13], Altun ve ark. [14], Altunatmaz ve ark. [15] ve Oroian ve ark.'nın [23] sonuçlarından yüksek olmasına rağmen, Akbari ve ark. [16] ve Erbilir ve Erdoğrul'un [25] sonuçlarıyla benzerlik göstermektedir. Türk Gıda Kodeksi Bulaşanlar Yönetmeliği'nde [17] balda bulunabilecek Cd miktarı belirtilmemiştir. Ancak balda bulunan Cd miktarı, gıda takviyelerinde bulunabilecek en yüksek Cd miktarıyla da değerlendirilmiştir [24]. Bahsedilen yönetmelikte [17] ve AB mevzuatında [18], gıda takviyelerinde bulunabilecek en yüksek Cd miktarı $1,0 \mathrm{mg} / \mathrm{kg}$ olarak belirlenmiştir. Ayrıca, insanlar için geçici tolere edilebilir kadmiyum miktarı günlük (PTDI) 0,8 $\mu \mathrm{g} / \mathrm{kg}$ canlı ağırlık, aylık (PTMI) $25 \mu \mathrm{g} / \mathrm{kg}$ canlı ağırlık olarak tespit edilmiştir [19]. Bal örneklerinde tespit edilen ortalama Cd düzeyi, söz konusu limit değerler dikkate alındığında düşük olsa da, bazı bal örneklerinde daha yüksek düzeyde $(3514,1 \mu \mathrm{g} / \mathrm{kg})$ Cd bulunmasının, tüketici sağlı̆̆ açısından potansiyel bir risk oluşturabileceği söylenebilir. Kadmiyum, insan faaliyetleriyle havaya, karaya ve suya yayılan elementlerden biridir. Genel olarak, çevrenin Cd ile kontaminasyonu, Cd'un üretilmesi ve kullanılmasıyla ve Cd içeren atıkların bertaraf edilmesiyle meydana geldiği [19] düşünülmektedir. Balın Cd ile kontaminasyonu metal kaplama, boyalar ve temas ettiği plastikler yoluyla da olabilmektedir [23]. Kadmiyumun, IARC tarafindan kanserojen madde olarak tanımlandığı, böbreklerde birikerek böbrek fonksiyon bozukluklarına yol açtığı ve kronik obstrüktif solunum yolu hastalığının da, Cd'un uzun süre solunmasıyla ilişkili olduğu bildirilmektedir [19].

Analiz edilen bal örneklerinde en düşük $0,0 \mu \mathrm{g} / \mathrm{kg}$, en yüksek $5051,7 \mu \mathrm{g} / \mathrm{kg}$, ortalama $409,9 \mu \mathrm{g} / \mathrm{kg} \mathrm{Pb}$ tespit edilmiştir (Tablo 3). Tuzen ve ark. [13], en düşük Pb konsantrasyonunu (8,4 $\mu \mathrm{g} / \mathrm{kg}$ ) Samsun ballarında, en yüksek $\mathrm{Pb}$ konsantrasyonunu ise $(106 \mu \mathrm{g} / \mathrm{kg})$ Erzurum ballarında tespit etmişlerdir. Başka bir çalışmada [15], ülkemizin farklı bölgelerinde üretilen ballarda ortalama $349(0,0-3035) \mu \mathrm{g} / \mathrm{kg}$ Pb bulunmuş; Altun ve ark. [14] tarafindan yapılan araştırmada ise Doğu ve Güneydoğu Bölgelerinde toplanan bal örneklerinde $\mathrm{Pb}$ tespit edilmemiştir $(<1$ $\mu \mathrm{g} / \mathrm{kg})$. Kurşun konsantrasyonu, İran' ın çeşitli bölgelerinde üretilen ballarda ortalama olarak $110(40-340) \mu \mathrm{g} / \mathrm{kg}$ [16] ve $80(60-120) \mu \mathrm{g} / \mathrm{kg}$ [22] düzeylerinde saptanırken, Macaristan'da üretilen ballarda ortalama 45,4 (11,2 133) $\mu \mathrm{g} / \mathrm{kg}$ [5], Romanya'da üretilen ballarda ortalama 51,67 (20,11 - 142,28) $\mu \mathrm{g} / \mathrm{kg}$ [23] olarak tespit edilmiştir. Bu çalışmamızda bal örneklerinde saptanan $\mathrm{Pb}$ miktarı yukarıda bahsedilen çalışmaların sonuçlarından yüksektir. Türk Gıda Kodeksi Bulaşanlar Yönetmeliği’nde [17] balda bulunabilecek Pb miktarı belirtilmemiştir. Ancak bu çalışmada, bal örneklerinin yaklaşık yarısında tespit edilen $\mathrm{Pb}$ düzeyinin, $\mathrm{AB}$ mevzuatında belirtilen maksimum düzeyden $(0.10 \mathrm{mg} / \mathrm{kg})$ [18] yüksek olması, tüketici sağlığı açısından potansiyel bir risk oluşturabileceği anlamına gelmektedir. Kurşun, çevrede, kentsel ve kırsal alanlarda yaygın olarak yayılan ağır bir metaldir. Kurşun kontaminasyonunun, çoğunlukla endüstriyel faaliyetlerden olmak üzere birçok kaynaktan meydana geldiği, özellikle maden eritme, işleme, kullanma, geri dönüşüm veya imhası sırasında kurşunun çevreye yayıldığı rapor edilmektedir [19, 23]. Gıdaların $\mathrm{Pb}$ ile kontaminasyonunun önlenmesinde ve kontrolünde $\mathrm{Pb}$ lehimli konserve kutularının kullanılmaması, petrol ve boyada $\mathrm{Pb}$ kullanımının düzenlenmesi, sudaki $\mathrm{Pb}$ miktarlarının kontrol 
edilmesi ve iyi tarım uygulamalarının önemli olduğu bildirilmektedir [20]. İnorganik Pb bileşikleri, IARC tarafından insanlar için muhtemel kanserojen madde olarak sınıflandırılmıştır [19].

Sonuç olarak, bu çalışma kapsamında incelenen ve Elazığ'da tüketime sunulan bal örneklerinde ağır metal miktarları farklılık göstermiştir. Balda bulunan mineral madde içerikleri üzerinde bal arılarının türü, coğrafik bölgeler, bitki türleri, endüstriyel kirlilik, bala uygulanan hatalı işlemler, metal kaplar veya ekipmanla temas ve zirai kimyasal maddeler $[5,7,11,13]$ gibi birçok faktör etkilidir. Balda tespit edilen $\mathrm{Al}$ ve As düzeylerinin insan sağ lığı açısından risk oluşturmayacak derecede düşük olduğu, buna karşıllı $\mathrm{Cd}$ ve $\mathrm{Pb}$ düzeylerinin tüketici sağlı̆̆ açısından potansiyel bir risk olabileceği söylenebilir. Toksik metallerle yüksek düzeyde kontamine gıdalar tüketiciler tarafından aldığında metal toksisitesi oluşabileceği gibi, az miktarda metallere uzun süre maruz kalmanın da, zaman içinde kümülatif etkilerden dolayı kronik toksisiteye neden olabileceği bilinmektedir [24]. Balların ağır metallerle kontaminasyonunun azaltılmasında, tarım ilaçlarının yoğun kullanıldığı çevrelerde ve şehir merkezlerine, otoyol ve sanayi tesislerine yakın bölgelerde bal üretiminin yapılmaması gerekmektedir $[11,13]$. Ayrıca, ağır metal içermeyen arııılık ilaçları kullanılmalıdır. Bu konularda, bal üreticilerinin bilinçlendirilmesi önem arz etmektedir. Diğer taraftan, balların ağır metal düzeylerinin belirlenmesi, hem çevrenin ağır metallerle kontaminasyonu nedeniyle oluşabilecek sorunların önlenmesine, hem de toksik metallerin balda bulunabilecek maksimum limitlerinin belirlenmesine katkı sağlayacağı düşünülmektedir. Ayrıca, Elazı ̆̆'da üretilen ve tüketilen balların içerdikleri mineral maddeler bakımından farklılıklarının nedenlerini belirlemek için arı kolonilerinin, coğrafi alanların ve çiçek türlerinin de dikkate alınarak kapsamlı bir araştırma yapılması gerekmektedir.

\section{Kaynaklar}

[1] Tarım ve Orman Bakanlığı. Türk Gıda Kodeksi Bal Tebliği Tebliğ No: 2012/58, Resmi Gazete, 27 Temmuz 2012, Sayı: 28366, Ankara, 2012.

[2] Tarımsal Ekonomi ve Politika Geliştirme Enstitüsü. Tarım Ürünleri Piyasaları - Arıcılık. Tarım ve Orman Bakanlığı, Temmuz 2018, Ürün No: 26, Ankara, 2018.

[3] Khan SU, Anjum S, Rahman K, Ansari MJ, Khan WU, Kamal S, Khattak B, Muhammad A, ve diğerleri. Honey: Single food stuff comprises many drugs. Saudi J Biol Sci 2018; 25: 320-325.

[4] Cianciosi D, Forbes-Hernández TY, Afrin S, Gasparrini M, Reboredo-Rodriguez P, Manna PP, Zhang J, Lamas LB ve diğerleri. Phenolic compounds in honey and their associated health benefits: A review. Molecules 2018; 23: 2322, doi:10.3390/molecules23092322.

[5] Czipa N, Andrasi D, Kovacs B. Determination of essential and toxic elements in Hungarian honeys. Food Chem 2015; 175: 536-542.

[6] Kadri SM, Zaluski R, de Oliveira Orsi R. Nutritional and mineral contents of honey extracted by centrifugation and pressed processes. Food Chem 2017; 218: 237-241.

[7] Rashed MN, Soltan ME. Major and trace elements in different types of Egyptian mono-floral and non-floral bee honeys. J Food Compos Anal 2004; 17: 725-735.

[8] Ernest E, Okeke Onyeka O, Ozuah A., Benard N. Comparative assessment of the heavy and trace metal levels in honey produced within Nsukka and Enugu Metropolis. Food Public Health 2018; 8(2): 42-46.

[9] Jaishankar M, Tseten T, Anbalagan N, Mathew BB, Beeregowda KN. Toxicity, mechanism and health effects of some heavy metals. Interdiscip Toxicol 2014; 7(2): 60-72.

[10] Antoine JMR, Hoo Fung LA, Grant CN. Assessment of the potential health risks associated with the aluminium, arsenic, cadmium and lead content in selected fruits and vegetables grown in Jamaica. Toxicol Rep 2017; 4: 181-187.

[11] Yarsan E, Karacal F, Ibrahim IG, Dikmen B, Koksal A, Das YK. Contents of some metals in honeys from different regions in Turkey. Bull Environ Contam Toxicol 2007; 79: 255-258.

[12] Sitarz-Palczak E, Kalembkiewicz J, Dagmara Galas D. Evaluation of the content of selected heavy metals in samples of Polish honeys. J Ecol Eng 2015; 16(3): 130-138.

[13] Tuzen M, Silici S, Mendil D, Soylak M. Trace element levels in honeys from different regions of Turkey. Food Chem 2007; 103: 325-330.

[14] Altun SK, Dinç H, Paksoy N, Temamoğulları FK, Savrunlu M. Analyses of mineral content and heavy metal of honey samples from south and east region of Turkey by using ICP-MS. Int J Anal Chem 2017; Article ID: 6391454, p. 6, https://doi.org/10.1155/2017/6391454.

[15] Altunatmaz SS, Tarhan D, Aksu F, Ozsobaci NP, Or ME., Barutçu UB. Levels of chromium, copper, iron, magnesium, manganese, selenium, zinc, cadmium, lead and aluminium of honey varieties produced in Turkey. Food Sci Technol Campinas 2018; DOI: https://doi.org/10.1590/fst.19718. Ahead of Print, 1-6.

[16] Akbari B, Gharanfoli F, Khayyat MH, Khashyarmanesh Z, Rezaee R Karimi G. Determination of heavy metals in different honey brands from Iranian markets. Food Addit Contam B 2012; 5(2): 105-111.

[17] Türk Gıda Kodeksi Bulaşanlar Yönetmeliği. Resmi Gazete, 29.12.2011, Sayı: 28157 (3. Mükerrer), Ankara.

[18] Commission Regulation (EC) No 1881/2006, Setting maximum levels for certain contaminants in foodstuffs (OJ L 364 , 20.12.2006, p. 5). 2006R1881 - EN - 01.04.2016. 
[19] Food and Agriculture Organization. Working document for information and use in discussion related to contaminants andd toxins in the GSCTFF. Joint FAO / WHO Food Standards Programme Codex Committee on Contaminants in Foods, CF/5 INF/1, Fifth Session, 21 - 25 March 2011, The Hague, The Netherlands, 2011.

[20] World Health Organization. Evaluation of certain food additives and contaminants: seventy-third report of the Joint FAO/WHO Expert Committee on Food Additives. WHO technical report series, no. 960, IV. Series, Geneva, Switzerland, 2011.

[21] Döker S, Aydemir O, Uslu M. Evaluation of digestion procedures for trace element analysis of Cankırı, Turkey honey by inductively coupled plasma mass spectrometry. Anal Lett 2014; 47: 2080-2094.

[22] Mahmoudi R, Mardani K, Rahimi B. Analysis of heavy metals in honey from north-western regions of Iran. J Chem Health Risks 2015; 5(4): 251-256.

[23] Oroian M, Prisacaru A, Hretcanu EC, Stroe S-G, Leahu A, Buculei A. Heavy metals profile in honey as a potential indicator of botanical and geographical origin. Int J Food Prop 2016; 19: 1825-1836.

[24] Wetwitayaklung P, Wangwattana B, Narakornwit W. Determination of trace-elements and toxic heavy minerals in Thai longan, litchi and Siam weed honeys using ICP-MS. IFRJ 2018; 25(4): 1464-1473.

[25] Erbilir F, Erdoğrul Ö. Determination of heavy metals in honey in Kahramanmaraş city, Turkey. Environ Monitoring Assesment 2005; 109: 181-187. 